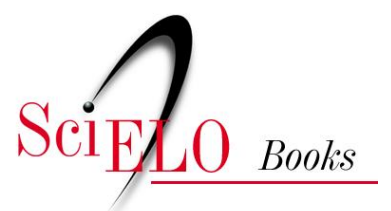

\title{
Aos guerreiros do arco-íris
}

\author{
Manoel Moreno Fraginals
}

FRAGINALS, MM. Aos Guerreiros do Arco-Íris. In: ALMEIDA, JP. A extinção do arco-íris: ecologia e história [online]. Rio de Janeiro: Centro Edelstein de Pesquisa Social, 2008, pp. 6. ISBN 978-85-99662-69-4. Available from SciELO Books $<$ http://books.scielo.org $>$.

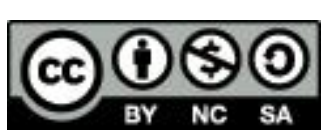

All the contents of this chapter, except where otherwise noted, is licensed under a Creative Commons Attribution-Non Commercial-ShareAlike 3.0 Unported.

Todo o conteúdo deste capítulo, exceto quando houver ressalva, é publicado sob a licença Creative Commons Atribuição Uso Não Comercial - Partilha nos Mesmos Termos 3.0 Não adaptada.

Todo el contenido de este capítulo, excepto donde se indique lo contrario, está bajo licencia de la licencia Creative Commons Reconocimento-NoComercial-CompartirIgual 3.0 Unported. 
Quem não sente alegria infinita de estar aqui neste mundo revolto e mutante, perigoso e belo, doloroso e sangrento como um parto, mas como ele criador de uma nova vida, está incapacitado para escrever história. E quem, sobre todas as pequenas questiúnculas pessoais não sente seu dever moral entregar-se todo para a revolução, e está consciente dos defeitos que arrasta e não deve transmitir, quem nesta hora não sente o dever de estar aqui, ainda que simplesmente queimando-se como lenha neste fogo, quem não está além de seu livro e do meu, do escrevo-lhea-nota-de-seu-livro para que logo você-me-escreva-a-nota-de-meu-livro, jamais poderá ser um historiador.

Manoel Moreno Fraginals

Aos Guerreiros do Arco-Íris 